\title{
Effect of Weather and Date of Transplanting on Caseworm (Nymphula depunctalis) Incidence
}

\author{
Rituraj Saikia*, Mayuri Baruah and Ajay Kumar Medhi
}

Regional Agricultural Research Station, Assam Agricultural University, Titabor, Assam, India

*Corresponding author

Keywords

N. depunctalis, Rice, Weather parameters, Date of transplanting

\section{Article Info}

Accepted:

20 January 2021

Available Online:

10 February 2021
Caseworm, Nymphula depunctalis infestation was started from very initial stage (15 DAT) and lasted upto 75 DAT. The highest peak (21.25 percent) was recorded at 45 DAT while the infestation was above ETL upto 60 DAT. Among the weather parameters, rainfall showed significant positive correlation $(\mathrm{r}=0.828)$ and minimum temperature as well as number of rainy days showed nonsignificant but strong positive correlation with N.depunctalis infestation ( $\mathrm{r}=0.789 \& 0.806$, respectively). Study on transplanting dates showed a significant impact on the pest infestation. Crops which were transplanted before first half of July showed negligible infestation (3.2-6 percent). But when transplanting was done on $15^{\text {th }}$ of July, the crop was just above ETL and the last transplanting date ( $5^{\text {th }}$ August) was worst affected by $N$. depunctalis with 31.65 percent infestation. From the study, it can be recommended that transplanting of Sali rice should be done before $15^{\text {th }}$ of July in the $N$. depunctalis endemic areas.

\section{Introduction}

The rice caseworm, Nymphula depunctalis (Guenee) (pyralidae: Lepidoptera) is a serious pest of rice in Assam particularly in Sali season (monsoon crop:transplanted lowland rainfed rice and deep-water rice). $N$. depunctalis is widely distributed in rice growing counties of Asia, Australia, America and Africa (Dale, 1994). The pest occurs in the fields with prolonged standing water in the vegetative stage of the rice plant (Pathak and Khan, 1994). Larvae of $N$. depunctalis are semi-aquatic in nature which requires standing water. Due to continuous rainfall and water stagnation in thefield of winter rice, infestation of $N$. depunctalis increased in a high rate during vegetative stage of the crop. In heavily infested area, entire crop may have to be resown or replanted (Srivastava, 
2012).Infestation of $N$. depunctalis is localized in nature (Islam et al., 2004), particularly in the areas where water stagnation is more or in the deeper part of the rice field. The larvae cut the leaf blade to produce a tubular leaf case and staying within the case, they scrap the green portion of the leaf leaving only the papery epidermis and veins. Infested plants appear whitish in colour due to scrapping of the green portion of the leaf but under heavy infestation they become straw coloured, remains stunted or die. Post infested areas show uneven flowering. Larval cases are found on plants and water surface and they move from one plant to another by floating on the standing water.

Information on incidence of $N$. depunctalis with date of transplanting is rare in our region where the pest is a major menace to the rice growing farmers. Moreover, influence of weather factors on $N$. depunctalis incidence is also rare. Therefore, the present investigation is undertaken to determine the effect of transplanting dates and weather parameters on the pest incidence.

\section{Materials and Methods}

The experiment was conducted at Regional Agricultural Research Station, Titabor which is the leading rice research station in entire northeastern regions of India. To study the influence of weather parameters on $N$. depunctalis incidence, a $400 \mathrm{~m}^{2}$ fixed plot was selected and observations on pest infestation were recorded at fortnightly interval starting from 15 days after transplanting (DAT) till last appearance of the pest. Crop was transplanted on $30^{\text {th }}$ July, 2020. Infestation percentages were estimated from 10 randomly selected plants by counting the number of damaged and healthy leaves and expressed in percentage. Daily weather parameters were collected from meteorological observatory unit of RARS, Titabor and fortnightly averages were worked out for correlation analysis. To observe the case worm incidence with date of transplanting, 6plots $\left(400 \mathrm{~m}^{2}\right.$ each) from the seed production blocks of RARS, Titabor were selected with 6 different dates of transplanting $\left(15^{\text {th }}\right.$ June $2020,25^{\text {th }}$ June, 2020, $05^{\text {th }}$ July $2020,15^{\text {th }}$ July, 2020, $25^{\text {th }}$ July and $5^{\text {th }}$ August, 2020). Ranjit variety was selected for the experiment as it is the most popular variety of Assam and has large area coverage at the station. Plots were chosen in such a way that each plot provide a homogenous micro climate. Plots were selected in the boarder side area with more stagnant water. Observations on $N$. depunctalis incidence were taken at $30^{\text {th }}$ and $45^{\text {th }}$ DAT as these are the most vulnerable period of rice to $N$. depunctalis attack and mean of the two dates were worked out. Crop was grown following the standard package of practices for Sali rice in Assam except utilizing the pest control measures.

\section{Results and Discussion}

Infestation of $N$. depunctalis was started from the initial stage and lasted upto 75 DAT (Table 1). The highest infestation rate 23.33 percent was recorded at 45 DAT on $10^{\text {th }}$ September, 2020 which gradually declined and no infestation was recorded at $90 \mathrm{DAT}$ on $22^{\text {nd }}$ October, 2020. Dumra and Srivastava (2019) reported that $N$. depunctalis preferred early stage of rice crop and the maximum damage occurred within 30 days of transplanting. However, during present investigation, the highest infestation was recorded within $30^{\text {th }}$ to $45^{\text {th }} \mathrm{DAT}$ and the infestation rate was considerably high (16.33 percent) upto60 DAT. Singh and Singh (2010) also reported that $N$. depunctalis prefer seedling and tillering stage of rice crop but does not occur after maximum tillering stage. Ramasubbaiah et al., (1978), Litsinger et al., (1994), Pulin and Khound (1998) and many other earlier researchers had reported highest 
level of damage by case worm within 4-6 weeks after transplanting. But during present investigation, $N$. depunctalis infestation above ETL upto60 days might be due to climate change and other favourable factors like reduction of their bio control agents etc. High rainfall as well as more numbers of rainy days might favoured the semiaquatic pest to infest rice crop upto75 days.

Correlation analysis of $N$. depunctalis infestation percentage with meteorological parameters showed significant positive correlation $(\mathrm{r}=0.828)$ only with rainfall (Table 1). While minimum temperature $(\mathrm{r}=0.789)$ and number of rainy days $(\mathrm{r}=0.806)$ also showed non-significant but strong correlation and morning relative humidity showed moderate degree negative correlation $(\mathrm{r}=-0.551)$ with $N$. depunctalis infestation. While the other meteorological parameters showed weak correlation. The findings are in strong confirmation with Kalita et al., (2019). They reported significant positive correlation of $N$. depunctalis infestation with maximum temperature, minimum temperature and rainfall and significant negative correlation with morning relative humidity. Gogoi and Bora (2013) also reported positive correlation between $N$. depunctalis incidence and total rainfall. Fei et al., (1995) found that climatic factors like relative humidity, total rainy days and temperature were responsible for population build-up of $N$. depunctalis.

The study on transplanting date on $N$. depunctalis infestation showed a greater impact of transplanting dates on the pest infestation (Table 2). Crop transplanted during June and early July showed negligible infestation by the pest, which was below economic threshold level.

While the crop when transplanted on $15^{\text {th }}$ of July was just above ETL on $30^{\text {th }}$ and $45^{\text {th }}$ DAT (mean $=13$ percent). But the last transplanting date $\left(5^{\text {th }}\right.$ August, 2020) was worst affected by case worm with 31.65 percent infestation and the crop was unable to recover fully from the pest injury. Therefore, to minimize the attack of $N$. depunctalis on Sali rice, transplanting should be done within first half of July.

Table.1 Infestation percentage of $N$. depunctalisat fortnightly interval and average weather parameters

\begin{tabular}{|c|c|c|c|c|c|c|c|c|}
\hline $\begin{array}{c}\text { Date of } \\
\text { observation }\end{array}$ & $\begin{array}{l}\text { Infestation } \\
\text { percentage }\end{array}$ & \multicolumn{2}{|c|}{ Temperature } & \multicolumn{2}{|c|}{ Relative humidity } & Rainfall & $\begin{array}{c}\text { No. of } \\
\text { rainy } \\
\text { days }\end{array}$ & $\begin{array}{c}\text { Bright } \\
\text { sunshine } \\
\text { hours }\end{array}$ \\
\hline $\mathbf{1 3 . 0 8 . 2 0 2 0}$ & 19.00 & 33.95 & 24.97 & 95.60 & 77.07 & 175.90 & 9 & 4.85 \\
\hline $\mathbf{2 7 . 0 8 . 2 0 2 0}$ & 18.60 & 33.41 & 23.88 & 94.64 & 78.79 & 102.70 & 7 & 5.05 \\
\hline $\mathbf{1 0 . 0 9 . 2 0 2 0}$ & 21.25 & 33.08 & 23.94 & 95.36 & 81.07 & 111.00 & 6 & 3.56 \\
\hline $\mathbf{2 4 . 0 9 . 2 0 2 0}$ & 16.33 & 33.22 & 23.77 & 95.86 & 81.29 & 122.60 & 9 & 3.22 \\
\hline $\mathbf{0 8 . 1 0 . 2 0 2 0}$ & 4.00 & 32.70 & 23.45 & 96.43 & 82.00 & 57.00 & 5 & 3.38 \\
\hline $\mathbf{2 2 . 1 0 . 2 0 2 0}$ & 0.00 & 34.43 & 22.61 & 95.64 & 72.43 & 42.40 & 1 & 5.50 \\
\hline Correlation coefficient & $\mathbf{- 0 . 2 5 3}$ & $\mathbf{0 . 7 8 9}$ & $\mathbf{- 0 . 5 5 1}$ & $\mathbf{0 . 4 3 9}$ & $\mathbf{0 . 8 2 8}$ & $\mathbf{0 . 8 0 6}$ & $\mathbf{- 0 . 2 0}$ \\
\hline
\end{tabular}

*Correlation is significant at the 0.05 level 
Table.2 Infestation percentage of $N$. depunctalis with date of transplanting

\begin{tabular}{|c|c|c|c|}
\hline $\begin{array}{c}\text { Date of } \\
\text { transplanting }\end{array}$ & 30 DAT & 45 DAT & $\begin{array}{c}\text { Mean infestation } \\
\text { percentage }\end{array}$ \\
\hline $\begin{array}{c}\mathbf{1 5}^{\text {th }} \text { June } \\
\mathbf{2 0 2 0}\end{array}$ & 3.6 & 2.8 & 3.2 \\
\hline $\begin{array}{c}\mathbf{2 5}^{\text {th }} \mathbf{J u n e} \\
\mathbf{2 0 2 0}\end{array}$ & 5.8 & 6.2 & 6 \\
\hline $\mathbf{0 5}^{\text {th }} \mathbf{J u l y} \mathbf{2 0 2 0}$ & 4.2 & 5.5 & 4.85 \\
\hline $\begin{array}{c}\mathbf{1 5}^{\text {th }} \mathbf{J u l y} \\
\mathbf{2 0 2 0}\end{array}$ & 12.6 & 13.4 & 13 \\
\hline $\begin{array}{c}\mathbf{2 5}^{\text {th }} \mathbf{J u l y} \\
\mathbf{2 0 2 0}\end{array}$ & 18.8 & 20.2 & 19 \\
\hline $\begin{array}{c}\mathbf{0 5} \\
\mathbf{2 0 2 0}\end{array}$ & 30.5 & 32.8 & 31.65 \\
\hline
\end{tabular}

\section{References}

Dale, D.1994. Insect pests of the rice plant their biology and ecology. In: Biology and Management of Rice Insects. Heinrichs EA (Ed.). IRRI, Los-Banos, the Philippines. Pp. 363-485.

Dumra, N. and Srivastava, A. 2019. Seasonal abundance of rice caseworm and whorl maggot under mid hill conditions of Himachal Pradesh, India. Journal of Entomology and Zoology Studies. 7(4): 61-66.

Fei, H., Su, Q. and Zhang, X. 1995. Effects of immigrated population and climatic factors on field population dynamics of rice caseworm. Acta-PhytophylacicaSinica. 22(3): 193-197.

Gogoi, H. and Bora, D. 2013. High yielding rice cultivars, high rainfall and high humidity favour Nymphula depunctalis (Lepidoptera: Pyralidae) to reach the major pest status: A study in Dhemaji district of Assam. Notational Academy Science Letters. 36:469-475.

Islam, Z., Heong, K.L., Bell, M. and Hazarika, L.K. 2004. Current status of rice pests and their management in Assam, India -a discussion with extension agents. Int rice res newsletter. (Manila) 29 (2): 89-91.

Kalita, S., Hazarika, L.K. and Deka, R.L. 2020. Effect of weather parameters and varieties on occurrence of insect pests and natural enemies of rice. Journal of Pharmacognosy and Phytochemistry. 9(5): 2429-2438.

Litsinger, J. A., Bandong, J. P. and Chantaraprapha, N. 1994. Mass rearing, larval behaviour and effects of plant age on the rice caseworm, Nymphula depunctalis (Guenee) (Lepidoptera Pyralidae). Crop Protection. 13(7): 494-502.

Pathak, M.D. and Khan, Z.R. 1994. Insect Pests of Rice. International Rice Research Institute and International Centre of Insect Physiology and Ecology, Manila, the Philippines.

Pulin, P., Khound, J.N. and Patgiri, P. 1998. Seasonal incidence of rice caseworm Nymphula depunctalis (Guen.) in Ahu and Sali rice. J Agril Sc. Soc. North East India.; 11(2):241-243.

Ramasubbaiah, K., Rao, P. S. and Ahmed, K. 1978. A note on bionomics and control of rice caseworm. Ind J Entom. 40(1): 91-92. 
Srivastava, A., Sharma, P.K., Singh, A.P. and Upmanyu, S. 2012. Field efficacy of certain new insecticides against caseworm, Nymphula depunctalis stagnalis on paddy in Himachal Pradesh, India, Agric. Sci. Digest.
32(4): 348-350.

Singh, B.B. and Singh, R. 2010. Major Rice insect pests in northeastern UP. Int. J Lifesc. Bt \& Pharm. Res. 3(1):124143.

\section{How to cite this article:}

Rituraj Saikia, Mayuri Baruah and Ajay Kumar Medhi. 2021. Effect of Weather and Date of Transplanting on Caseworm (Nymphula depunctalis) Incidence. Int.J.Curr.Microbiol.App.Sci. 10(02): 2357-2361. doi: https://doi.org/10.20546/ijcmas.2021.1002.279 